\section{Violência em relações homoafetivas femininas: estatísticas invisíveis}

Melato, F.A.

Universidade Federal de Viçosa

Carezzato, C.L.

Centro de Medicina Legal (CEMEL) - Departamento de Patologia e Medicina Legal - FMRP-USP Contato: mag@fmrp.usp.br

\section{Guimarães, M.A}

Centro de Medicina Legal (CEMEL) - Departamento de Patologia e Medicina Legal - FMRP-USP Contato: mag@fmrp.usp.br

PALAVRAS-CHAVE: Violência, Mulheres, Homoafetividade, Bioética

RESUMO: Introdução - No tema violência contra a mulher, geralmente aborda-se a violência masculina contra mulheres. A violência entre mulheres é assunto pouco discutido. $\mathrm{Na}$ definição de violência doméstica como qualquer agressão física, sexual ou psicológica entre casais, na qual um dos indivíduos tenta estabelecer o controle e poder sobre seu parceiro [1], é preciso incluir o abuso financeiro ou patrimonial, a coerção reprodutiva, a violência moral e a cultural [2]. Essas violências ocorrem em toda a sociedade, mas principalmente em núcleos familiares. Apesar da invisibilidade midiática e estatística, a violência conjugal lésbica é tão agressiva quanto qualquer outra forma de violência doméstica. Acrescentam-se fatores especificamente associados à orientação sexual lésbica num contexto heterossexista, heteronormativo e lesbofóbico, gerando opressões, como: isolamento, falta de redes de apoio, assédio e fetichização, ausência de formação de agentes policiais e de saúde e a revelação de orientação sexual não-consentida [3]. Métodos - Revisão da literatura. Rseultados - Estudos internacionais revelam que a incidência de violência conjugal é semelhante em casais heteroafetivos e homoafetivos [3]. A subnotificação da violência entre mulheres revela-se nos apenas $0,3 \%$ de denúncias recebidas no Ligue 180 - número de atendimento à mulher - no balanço de 2016 [4]. A Lei Maria da Penha possibilitou a análise de denúncias e investigações, sendo estimadas 374 mulheres presas desde sua vigência. O que dificulta uma análise dos dados é o perfil das vítimas não divulgado, impossibilitando saber quantas mulheres em relação íntima ou simplesmente familiar foram agredidas nesse intervalo [4]. O número de denúncias vem aumentando com a divulgação de que a Lei abrange também esses casos. Nos primeiros 6 anos da Lei foram presas 140 mulheres e, no sétimo, 234, um aumento de 174\% [5]. Dados da Secretaria de Políticas para Mulheres até 2011, contabilizaram a expedição de aproximadamente, 281.302 medidas protetivas, estimando-se que, até 2012, este número tenha ultrapassado o marco de 350 mil. Conclusão Reforçar a ideia de que discussões bioéticas abrangendo a violência contra a mulher, incluindo aquelas em relações homoafetivas, podem aumentar a capacidade institucional de protege-las, visando prevenir e coibir as violências.

\section{REFERÊNCIAS}

[1] N. Farley (1992). In S. H. Dworkin \& F. J. Gutierrez (eds.). Counseling Gay Men and Lesbians: journey to the end of the rainbow.

[2] L. Casique Casique, A.R.F. Furegato. Rev Latino-am Enfermagem 2006; 14(6).

[3] 'Entre duas mulheres isso não acontece' - Um estudo exploratório sobre violência conjugal lésbica

[4] Secretaria Especial de Políticas para as Mulheres. (2016). www.spm.gov.br/balanco180_2016-3.pdf

[5] Fontenele, M. (2015). http://tribunadoceara.uol.com.br/noticias/cotidiano-2/criadapara-proteger-a-mulher-lei-maria-da-penha-ja-puniu-quase400-agressoras/ 